\title{
Tradisi Lopis Raksasa dalam Perspektif Kerukunan Umat Beragama di Kota Pekalongan
}

\author{
Rosidin \\ Badan Litbang dan Diklat Kementerian Agama RI \\ nazalnifa@yahoo.co.id
}

\begin{abstract}
This study aims to address the origin and the meaning for the community of tradition the "Giant Lopis " (Lopis Raksasa) in the perspective of religious harmony. The research has been conducted in a descriptive - qualitative approach. In this study, it is attempt to seek a thorough description and depth about the "Giant Lopis" tradition. Furthermore, this study is to find out how the tradition plays a role in order to maintaining an harmony of community in Pekalongan municipality openly and naturally. The results of this study shows that, firstly, is that the tradition of the "Giant Lopis" is closely associated with the practise of fasting on the Shawwal month, which was initiated by KH. Abdullah Siradj of Krapyak in 1855. Subsequently, his followers gave the guests whose came for silaturrahmi with snacks lopis on the 8th day. Another version mentioned that the lopis tradition was inspired by the speech of President Sukarno in 1950s in Kebon Rodjo Pekalongan. Secondly, glutinous rice as the basic ingredient lopis highlights a symbolic of the close relationship that tied rigging as a stronger. At this point, banana leaf wrapping is a symbol that people have to be usefull and good within their social life. Finally, the tradition of the giant lopis has a value of harmony, that is, to encourage tolerance, equality, and mutual cooperation.
\end{abstract}

\begin{abstract}
Abstrak
Studi ini untuk mengetahui bagaimana asal mula, makna bagi masyarakat dan tradisi dalam perspektif kerukunan umat beragama. Pendekatan studi ini bersifat kualitatifdeskriptif. Artinya peneliti mencari deskripsi yang menyeluruh, mendalam, dan cermat tentang tradisi lupis raksasa. Selanjutnya, digambarkan bagaimana tradisi berperan dalam memelihara kerukunan umat secara terbuka alamiah.Adapun hasil penelitian ini menunjukkan bahwa: pertama, tradisi lupis raksasa terkait erat dengan amalan puasa Syawal KH.Abdullah Siradj di daerah Krapyak tahun 1855. Dalam perkembangan pengikutnya menjamu tamu yang datang bersilaturrahimi dengan jajanan lupis pada hari ke-8. Versi lain menyebutkan tradisi lupis terinspirasi pidato Presiden Soekarno pada tahun 1950 di Kebon Rodjo Pekalongan. Kedua, beras ketan sebagai bahan dasar lupis simbol hubungan erat diikat tali temali sebagai pengokoh. Daun pisang pembungkusnya simbol sifat selalu bermanfaat dalam hidup bermasyarakat. Ketiga, tradisi lupis raksasa ini mempunyai nilai kerukunan dalam hal sikap toleransi, kesetaraan dan saling kerjasama.
\end{abstract}

Keywords : tradition, giant Lopis, harmony, tolerance, equality and cooperation 


\section{A. Pendahuluan}

Indonesia adalah negara unik dan kompleks yang kaya akan tradisi dan adat istiadat. Sebagaian tradisi dapat bertahan eksis di masyarakat dan terjaga kemurniannya dan sebagian lainnya ada yang sudah mengalami perubahan bentuk maupun makna karena dimasuki oleh unsur-unsur keagamaan. Salah satunya adalah tradisi lupis raksasa yang sangat terkait erat dengan berakhirnya puasa ramadhan atau idul fitri. Nama tradisi lupis raksasa adalah tradisi syawalan setelah lebaran Idul Fitri. Syawalan merupakan tradisi yang menjadi kebiasaan bagi mayarakat Indonesia, walaupun hakekatnya tradisi ini datang setelah muncul inisiatif dari beberapa kalangan ulama terdahulu sebagai tradisi untuk mengemban amanah keagamaan yaitu dalam bentuk silaturahmi. Tradisi syawalan hadir sebagai konsep untuk membentuk masyarakat yang arif menjalani kehidupan yang penuh dengan tantangan ${ }^{1}$.

Setiap tradisi yang mampu bertahan lama, pastilah melalui proses evolusi kebudayaan yang panjang dan memiliki kesamaan akar historis. Evolusi yang diikuti akulturasi itu, pada akhirnya menimbulkan keselarasan dan kecocokan dengan masyarakat penganutnya. Kajian ini relevan guna mengungkap tradisi Lupis raksasa yang dilakukan oleh masyarakat Jawa khususnya Pekalongan secara turun-temurun.

Sementara itu tradisi syawalan menurut Umar Kayam (1997) merupakan kreatifitas akulturasi budaya Jawa dan Islam. Ketika Islam hendak bersinggungan dengan budaya Jawa, timbul keteganganketegangan yang muaranya menimbulkan disharmoni. Melihat fenomena itu, para ulama Jawa lantas menciptakan akulturasi-akulturasi budaya, yang memungkinkan agama baru itu diterima oleh masyarakat Jawa. Singkatnya, para ulama di Jawa dahulu dengan segenap kearifannya, mampu memadukan kedua budaya yang bertolak belakang, demi kesejahteraan dan kerukunan dalam kehidupan masyarakat ${ }^{2}$.

${ }^{1}$ Supandi, Makna Dan Pengaruh Tradisi Syawalan Bagi Masyarakat Multi-Agama Di Komplek Mandala Asri Yogyakarta. (Yogyakarta : Jurusan Perbandingan Agama Fakultas Ushuluddin Dan Pemikiran Islam Universitas Islam Negeri Sunan Kalijaga Yogyakarta: 2014), hal. 1

${ }^{2}$ Supandi. Makna Dan Pengaruh Tradisi Syawalan Bagi Masyarakat Multi-Agama Di Komplek Mandala Asri Yogyakarta. (Yogyakarta : Jurusan Perbandingan Agama Fakultas Ushuluddin Dan Pemikiran Islam Universitas Islam Negeri Sunan Kalijaga Yogyakarta; 2014), hal. 3 
Kerukunan merupakan pilar penting dalam kehidupan bangsa Indonesia yang majemuk baik dari aspek suku bangsa, adat istiadat, agama maupun kepercayaan lainnya. Hal ini akan meninbulkan persoalan dan problem tersendiri manakala tidak dikelola dan diantisipasi dengan baik. Salah satu peristiwa penting yang dapat mempererat kerukunan tanpa melihat latar belakang agama adalah pelestarian tradisi lupis raksasa di Kota Pekalongan.

Dengan demikian sebagai upaya menggali lebih dalam kaitan tradisi lupis raksasa dengan kerukunan umat beragama pada masayarakat maka perlu dilakukan kajian bagaimana "Tradisi Lupis Raksasa dalam Perspektif Kerukunan Umat Beragama" di Kota Pekalongan ini.

Pertanyaan yang muncul kemudian adalah bagaimana tradisi lupis raksasa berkembang, bagaimana Makna Tradisi Lupis raksasa dalam pandangan masyarakat dan bagaimana Tradisi Lupis Raksasa dalam perspektif Kerukunan Umat Beragama pada masyarakat Kota Pekalongan?

Tulisan ini menitikberatkan pada asal mula tradisi lupis raksasa dan pandangan masyarakat pada aspek kerukunan umat beragama di Kota Pekalongan.

Artikel ini bertujuan untuk mengetahui kinerja sebuah tranformasi pembelajaran, dalam kaitannya dengan tradisi lupis raksasa adalah sebuah upaya proses pembelajaran kepada masyarakat yang semula baru sebatas mengikuti tradisi ini setelah mengikuti dapat tumbuh sikap saling menghormati, toleransi, kerjasama dan menghargai pendapat orang lain dalam masyarakat pada umumnya, tanpa membedakan umat beragama lain ${ }^{3}$.

Metode yang digunakan dalam penelitian ini kualitatif - deskrptif, berupaya memperoleh data yang kongkrit mengenai pelaksanaan tradisi lupis raksasa oleh pemrakarsa, panitia dan pemerintah setempat. Pengumpulan data dilakukan melalui wawancara dan studi dokumen. Observasi dilakukan dengan melihat dokumentasi mengingat saat data di ambil tidak bersamaan waktunya dengan moment tradisi lupis raksasa yaitu bulan Syawal. Untuk mengetahui perspektif kerukunan umat beragama digali dengan menjaring pendapat dari tokoh masyarakat dan tokoh agama.

Penelitian ini dilakukan pada masyarakat Kota Pekalongan,

\footnotetext{
${ }^{3}$ Suharsimi Arikanto, Prosedur Penelitian Suatu Pendekatan Praktik, (Jakarta: PT Rineka Cipta, 2010), hal. 41
} 
terutama di Kecamatan Pekalongan Utara dengan pertimbangan bahwa tradisi lupis raksasa asal mula dari Krapyak yang masuk Pekalongan Utara. Pengumpulan data lapangan dilaksanakan pada bulan Desember 2015.

Analisis data dalam penelitian ini dilakukan bersamaan dengan pengumpulan data di lapangan, hal ini dilakukan untuk mengetahui sejauh mana data yang diambil. Setelah data yang terkumpul dipandang cukup dilakukan pengolahan data. Pengolahan data adalah mengubah data mentah agar menjadi data yang lebih bermakna ${ }^{4}$. Data dikumpulkan berdasarkan kategori data, kemudian dilakukan penafsiran data dalam bentuk diskripsi.

\section{B. Tradisi Syawalan sebuah Budaya Masyarakat}

Koentjaraningrat dalam Kebudayaan Jawa (1984) menerangkan bahwa salah satu tradisi dan budaya Islam Jawa yang masih hidup adalah adanya penghormatan kepada makam-makam orang suci, baik ulama atau kyai. Jika kaum santri datang ke makam untuk mendoakan orang yang telah meninggal agar diampuni dosanya oleh Allah SWT, maka kaum Islam abangan mendatangi makam sebagai tempat Pepundhen. Yaitu menjadikan makam sebagai sesembahan, yang dipui-puji, diberi sesaji, dan dimintai pertolongan ${ }^{5}$.

Sementara itu Umar Kayam dalam Dirhamsyah (2014) mengatakan bahwa Tradisi syawalan merupakan kreatifitas budaya jawa dan Islam. Ketika Islam hendak bersinggungan dengan budaya Jawa timbul ketegangan-ketegangan yang muaranya menimbulkan disharmoni. Sehingga para ulama menciptakan akulturasi-akulturasi budaya yang memungkinkan agama baru itu ditrima oleh masyarakat Jawa. Artinya, para ulama dahulu dengan segenap kearifannya mampu memadukan kedua budaya. Tradisi syawalan atau krapyakan ataupun lupisan sejatinya memiliki makna filosofis yang luar biasa, yaitu falsafah kebangsaan yang mengutamakan persatuan dan kesatuan, sebagaimana sila ketiga dari dasar negara Pancasila ${ }^{6}$.

4 Suharsimi Arikanto, Prosedur Penelitian Suatu Pendekatan Praktik, (Jakarta: PT Rineka Cipta, 2010) hal. 53-54

${ }^{5}$ Nanda. Sejarah Syawalan Kaliwungu. http://kaliwungu.org/sejarah-syawalankaliwungu, tgl 21 Desember 2015

${ }^{6}$ Dirhamsyah, M.,. Pekalongan Yang (Tak) Terlupakan sebuah Katalog Warisan Budaya Pekalongan. "Tradisi Syawalan di Krapyak". (Pekalongan: Kantor Perpustakaan dan Arsip Daerah Kota Pekalongan, 2014) hal. 98 


\section{Kerukunan Umat Beragama}

Kerukunan hidup beragama adalah suatu kondisi sosial dimana semua golongan agama bisa hidup bersama-sama tanpa mengurangi hak dasar masing-masing untuk melaksanakan kewajiban agamanya. Masingmasing hidup sebagai pemeluk agama yang baik, dalam keadaan rukun dan damai. Sementara itu dalam Peraturan Bersama Menteri Agama dan Menteri Dalam Negeri Nomor 9 dan 8 Tahun 2006 Pasal 1 ayat 1 ditegaskan bahwa kerukunan umat beragama adalah keadaan hubungan sesama umat beragama yang dilandasi toleransi, saling pengertian, saling menghormati, menghargai kesetaraan dalam pengamalan ajaran agamanya dan kerjasama dalam kehidupan bermasyarakat, berbangsa dan bernegara di dalam Negara Kesatuan Republik Indonesia berdasarkan Pancasila dan Undang-Undang Dasar Negara Republik Tahun 1945.

Persamaan esensial dari beberapa konsep kerukunan dapat diperoleh 3 (tiga) unsur yang menjadi variabel utama, sebagaiman Survey Indeks Kerukunan Umat Beragama di Indonesia Tahun 2015, yaitu Toleransi, Kesetaraan dan Kerjasama (Puslitbang Kehidupan, 2015: 6)

Toleransi dalam menurut Cahyu (2012) berasal dari kata tolerare yang berasal dari bahasa latin yang berarti dengan sabar membiarkan sesuatu. Jadi pengertian toleransi secara luas adalah suatu sikap atau perilaku manusia yang tidak menyimpang dari aturan, dimana seseorang menghargai atau menghormati setiap tindakan yang orang lain lakukan. Toleransi juga dapat dikatakan istilah dalam konteks sosial budaya dan agama yang berarti sikap dan perbuatan yang melarang adanya deskriminasi terhadap kelompok yang berbeda atau tidak dapat diterima oleh mayoritas dalam suatu masyarakat ${ }^{7}$.

Kesetaraan dimaknai sebagai pandangan dan sikap hidup menganggap semua orang adalah sama dalam hal hak maupun kewajiban. Hak atas melaksanakan agama beribadah dan kewajiban terhadap kehidupan bernegara dan bersosialisasi dengan penganut agama lain $^{8}$.

\footnotetext{
7 Tim Peneliti Puslitbang Kehidupan. "Survey Indeks Kerukunan Umat Beragama di Indonesia" Makalah Seminar hasil penelitian yang diselenggarakan oleh Puslitbang Kehidupan Keagamaan Badan Litbang dan Diklat Kementerian Agama RI pada tanggal 19 Nopember 2015 di Wisma Haji Jl. Jaksa Kebon Sirih Jakarta Pusat, 2015 hal. 6

${ }^{8}$ Tim Peneliti Puslitbang Kehidupan, 2015. "Survey Indeks Kerukunan Umat Beragama di Indonesia" Makalah Seminar hasil penelitian yang dselenggarakan oleh Puslitbang Kehidupan Keagamaan Badan Litbang dan Diklat Kementerian Agama RI pada tanggal 19 Nopember 2015 di Wisma Haji Jl. Jaksa Kebon Sirih Jakarta Pusat, hal. 7
} 
Lebih lanjut dikatakan bahwa ukuran kesetaraan meliputi : tingkatan yang sama dalam arti tidak ada superioritas, tidak diskriminatif dan hubungan timbal balik; mempunyai kesempatan yang sama dalam arti memberi kebebasan melakukan aktifitas keagamaan bagi orang lain dan berhati-hati (menjaga) terhadap orang lain; dan perlindungan, artinya perlindungan terhadap perbedaan dan penghinaan.

Kerjasama, berdasarkan Kamus Umum Bahasa Indonesia adalah kegiatan atau usaha yang dilakukan oleh beberapa orang (lembaga, dsb) untuk mencapai tujuan bersama9. Misalnya, dalam tindakan tolong menolong antar kelompok agama. Tindakan ini muncul ketika toleransi dan kesetaraan dihadapkan pada kondisi sosial dalam masyarakat. Pemahaman kerjasama menjadi penting mengingat hal ini akan memberikan gambaran menjaga hubungan sosial antar pemeluk agama menjadi rawan bahkan menimbulkan suatu konflik.

\section{Sekilas Kota Pekalongan}

Kota Pekalongan terletak di dataran rendah pantai utara Pulau Jawa, dengan ketinggian kurang lebih 1 meter di atas permukaan laut dengan posisi geografis antara 650 ' 42" s.d. $655^{\prime} 44^{\prime \prime}$ Lintang Selatan dan 109 37' 55" s.d. 109 42' 19" Bujur Timur serta dengan koordinat fiktif $510.00-518.00 \mathrm{Km}$ membujur dan $517.75-526.75 \mathrm{Km}$ melintang. Sedangkan batas wilayah secara administratif adalah sebelah Utara Laut Jawa, sebelah Timur Kabupaten Batang, sebelah Selatan Kabupaten Pekalongan dan Kabupaten Batang dan sebelah Barat Kabupaten Pekalongan ${ }^{10}$. Posisi ini menjadikan bahwa Kota Pekalongan sangat di topang dan diapit dua kabupaten dengan corak kondisi kekayaan alam yang hampir sama yang memperkaya keanekaragaman budaya dan alamnya.

Keadaaan tanah di Kota Pekalongan mempunyai Jarak terjauh dari Utara ke selatan $\pm 9 \mathrm{Km}$ dan dari Barat ke Timur $\pm 7 \mathrm{Km}$. Luas Kota Pekalongan adalah sekitar $45.25 \mathrm{Km}^{2}$. Jarak dari Kota Pekalongan ke

9 Tim Peneliti Puslitbang Kehidupan. "Survey Indeks Kerukunan Umat Beragama di Indonesia" Makalah Seminar hasil penelitian yang dselenggarakan oleh Puslitbang Kehidupan Keagamaan Badan Litbang dan Diklat Kementerian Agama RI pada tanggal 19 Nopember 2015 di Wisma Haji Jl. Jaksa Kebon Sirih Jakarta Pusat, 2015 hal. 7

${ }^{10}$ Seksi Integrasi Pengolahan dan Diseminasi Statistik. Kota Pekalongan Dalam Angka Tahun 2014. Pekalongan: Badan Pusat Statistik Kota Pekalongan, 2015 hal. 3 
beberapa kota adalah Semarang $101 \mathrm{Km}$, Jakarta $384 \mathrm{Km} \mathrm{3}$, Bandung $266 \mathrm{Km} \mathrm{4,} \mathrm{Surabaya} 488 \mathrm{Km} \mathrm{5,} \mathrm{Yogyakarta} 219 \mathrm{Km}$ 6, Kajen $28 \mathrm{Km} 7$, Batang $8 \mathrm{Km}$, Pemalang $35 \mathrm{Km}$, Tegal $65 \mathrm{Km}$, Slawi $80 \mathrm{Km}$ dan.Brebes 78 Km (IPDS BPS, 2015: 4).

Di lihat dari jarak dengan kota lain memang tidak berlebihan Kota Pekalongan sebagai eks-Karesiden Pekalongan. Selain faktor sejarah, jarak ke beberapa kota juga mendudukung dijadikannya Kota Pekalongan sebagai pusat pembantu gubernur.

Secara administratif Kota Pekalongan terbagi dalam 4 kecamatan dengan luas wilayah $4.525 \mathrm{Ha}$, atau $0,14 \%$ dari luas wilayah Jawa Tengah (Luas Jawa Tengah 3.254 ribu Ha). Kecamatan paling luas adalah Pekalongan Utara sekitar 33\% dari luas Kota Pekalongan (1.488 Ha) dan kecamatan paling kecil adalah Pekalongan Timur sekitar $21 \%$ dari Kota Pekalongan $952 \mathrm{Ha}^{11}$.

Jumlah penduduk Kota Pekalongan pada tahun 2014 adalah 293.704 jiwa., terdiri dari 146.863 laki-laki (50,00\%) dan 146.841 perempuan $(50,00 \%)$. Kepadatan penduduk di Kota Pekalongan cenderung meningkat seiring dengan kenaikan jumlah penduduk. Rasio ketergantungan (Dependency Ratio) Kota Pekalongan cukup kecil, hal ini disebabkan karena jumlah penduduk usia 15-64 tahun lebih besar dari penduduk usia 0-14 tahun dan 65 tahun ke atas ${ }^{12}$.

Kota Pekalongan merupakan kota aagmis dengan tagline Kota Batik. Namun demikian pemeluk agama selain Islam pun tidak sedikit. Dengan penduduk yang heterogen, tentu akan berpengaruh terhadap keyakinan yang dianutnya, sehingga jika digambarkan dalam tabel akan tampak sebagai berikut :

${ }^{11}$ Seksi Integrasi Pengolahan dan Diseminasi Statistik. Kota Pekalongan Dalam Angka Tahun 2014. Pekalongan: Badan Pusat Statistik Kota Pekalongan, 2015 hal. 5.

${ }^{12}$ Seksi Integrasi Pengolahan dan Diseminasi Statistik.. Kota Pekalongan Dalam Angka Tahun 2014. Pekalongan: Badan Pusat Statistik Kota Pekalongan, 2015 hal. 31-32 
Tabel 1. Agama Jumlah Tempat Ibadah dan Pemeluknya

\begin{tabular}{llll}
\hline \multicolumn{1}{c}{ AGAMA } & \multicolumn{1}{c}{ TEMPAT } & UNIT & PEMELUK \\
& IBADAH & & \\
\hline Islam & Masjid & 108 & 282.190 \\
& Musholla & 614 & \\
Kristen & Gereja & 7 & 5.811 \\
Katolik & Gereja & 7 & 3.976 \\
Hindu & Pura & 3 & 56 \\
Budha & Vihara & 5 & 1.610 \\
Konghuchu & Kelenteng & 1 & \\
Lainnya & & & 61 \\
\hline Sumbra
\end{tabular}

Sumber : BPS Kota Pekalongan, 2015: 46 dan 63 (diolah)

Dari tabel di atas dapat dikatakan bahwa potret keberagamaan di Kota Pekalongan cukup beragam dalam menganut kepercayaan, bahkan semua agama yang diakui oleh negara dianut oleh penduduk Pekalongan. Data pemeluk agama Konghuchu tidak ada namun ada 1 tempat ibadah sehingga umat agama Khonhuchu pun ada di Kota Pekalongan. Kondisi ini dapat dijadikan miniatur kerukunan umat beragama di Indonesia.

\section{E. Ragam Sosial Keagamaan Pekalongan Utara}

Tradisi Lupis Raksasa Kota Pekalongan berawal mula masuk wilayah kerja KUA Kecamatan Pekalongan Utara. Kecamatan Pekalongan Utara terdiri atas 10 Kelurahan, yaitu : Krapyak Lor, Krapyak Kidul, Panjang Wetan, Kandang Panjang, Kraton Lor, Dukuh, Degayu, Pabean, Bandengan dan Panjang Baru ${ }^{13}$.

Secara geografis wilayah Kecamatan Pekalongan Utara berbatasan dengan Kecamatan Pekalongan Timur di sebelah timur (bersebelahan dengan kelurahan Klego dan Gamer) Kecamatan Pekalongan Barat disebelah Barat (bersebelahan dengan Kraton Kidul) ${ }^{14}$.

Berdasarkan data sensus tahun 2008, penduduk Kecamatan Pekalongan Utara sebanyak 71.311 jiwa. Jika diklasifikasi menurut agama, mayoritas penduduk Kecamatan Pekalongan Utara bergama Islam yaitu

\footnotetext{
${ }^{13}$ KUA Pekalongan Utara, http://www.kemenagkotapekalongan.com/kuau.php, tanggal 10 Desember 2015, hal. 1

${ }^{14}$ Seksi Integrasi Pengolahan dan Diseminasi Statistik. Kecamatan Pekalongan Utama Dalam Angka Tahun 2014. Pekalongan: BPS Kota Pekalongan, 2015 hal 5
} 
sebanyak 66.159 jiwa. Yang beragama katolik sebanyak 2047. Kristen sebanyak 1753, Hindu sebanyak 480, Budha sebanyak 628 dan aliran kepercayaan dan lain-lain berjumlah 244 jiwa $^{15}$.

Mata pencaharian mayoritas penduduk kecamatan Pekalongan Utara adalah pedagang, yaitu sebanyak 35031 orang. Sisanya, secara berturut-turut nelayan (6210), konveksi (5310) buruh industri (11500), buruh bangunan (366), PNS (2500) dan pensiunan (4717) dan lain-lain (1226). Kecamatan Pekalongan Utara tergolong masyarakat relejius dengan memiliki 57 majelis ta'lim, 34 masjid, 125 musholla \& langgar, 2 gereja, 1 pura dan 2 vihara $^{16}$.

Tradisi lupis raksasa yang diadakan setiap tahun semula hanya di lakukan di kelurahan Krapyak Kidul Gang 8 di sekitar musholla Darunna'im. Untuk mengenal lebih jauh bagaimana tradisi dilaksanakan berikut digambarkan perayaan tradisi lopis raksasa pada tahun 2014 sebagai berikut :

Pelaksanaan tradisi syawalan atau lupis raksasa membutuhkan persiapan yang cukup matang. Ini harus diperhatikan mengingat tradisi lupis raksasa ini bukan saja milik warga sekitar musholla Darunna'im saja. Moment syawalan dan lupis raksasa kini sudah menjadi ikon sekaligus destinasi wisata bagi Pemerintah Kota Pekalongan. Bahkan pada perayaan tradisi tahun 2002 Musium Rekor Indonesia (MURI) memberikan penghargaan kepada masyarakat Krapyak Kidul Gang 8 Kota Pekalongan sebagai pembuat Lopis Raksasa terbesar.

Masyarakat selain yang tercantum dalam kepanitiaan ikut menerjunkan dirinya secara moril dan materiil pada saat persiapan, pelaksanaan dan pasca kegiatan tradisi syawalan dan lupis raksasa ini (Zainuddin Ismail, tgl 8 Desember 2015)

Pembuatan Lopis Raksasa

Keseluruhan waktu pembuatan lopis raksasa membutuhkan waktu 5 hari 4 malam. Di mulai dari satu hari setelah lebaran $(\mathrm{H}+1)$ sampai $\mathrm{H}+5$. Pada hari pertama, Selasa tanggal 29 Juli 2014 mulai jam 07.00 WIB lebih kurang 110 orang warga masyarakat dan panitia melakukan kegiatan kebersihan di dapur Lopis Raksasa yang baru saja di bangun. Mereka bahu-membahu membersihkan lantai, membersihkan dandang raksasa,

\footnotetext{
${ }^{15}$ Seksi Integrasi Pengolahan dan Diseminasi Statistik.. Kota Pekalongan Dalam Angka Tahun 2014. Pekalongan: Badan Pusat Statistik Kota Pekalongan, 2015.

${ }^{16}$ KUA Pekalongan Utara,. http://www.kemenagkotapekalongan.com/kuau.php, tanggal 10 Desember 2015, hal 3
} 
membersihkan dandang-dandang kecil, merangkai beratus-ratus daun pisang dengan biting, membersihkan kronjot raksasa dan hal-hal kecil lainnya.

Kegiatan pembuatan lopis raksasa dilakukan pada $\mathrm{H}+2$, $\mathrm{Rabu}, 30$ Juli 2014, sampai dengan hari Sabtu, 2 Agustus 2014 dengan bergotong royong melaksanakan kegiatan antara lain menyiapkan tungku untuk tempat dandang raksasa, mencuci dan membilas beras ketan, menumbuk beras ketan yang sudah setengah matang dari dandang-dandang kecil, menumbuk beras ketan tadi untuk kemudian dimasukkan ke dalam kronjot lopis raksasa hingga membentuk lupis berukuran raksasa, merebus lopis raksasa, memastikan api tetap menyala dengan bahan bakar kayu bekas pembuatan kapal yang mempunyai daya panas tinggi selama 24 jam, kemudian membalik lopis raksasa, merebus kembali selama 24 jam, setelah selesai kemudian lopis raksasa dientas dari dandang raksasa, membuat panggung lopis raksasa dan terakhir memindahkan lopis raksasa yang sudah matang ke lokasi pemotongan lopis raksasa (Zainudin Ismail, tgl 11 Desember 2015 dan buku laporan panitia).

Pemotongan Lopis Raksasa

Pusat perayaan tradisi lopis raksasa kali ini jatuh pada hari Senin, 4 Agustus 2014 bertempat di halaman Musholla Darunna'im, Jl. Jlamprang Krapyak Kidul Gang 8 Kota Pekalongan. Acara dihadiri oleh lebih kurang 2000 orang. Seluruh jajaran Muspida Kota Pekalongan dan Muspika Kecamatan Pekalongan Utara hadir pada perhelatan akbar tersebut. Memberi sambutan pada acara tersebut, Walikota Pekalongan, dr. H.M. Basyir Ahmad dan do'a KH. Zainudin Ismail. Puncak acara yaitu pemotongan Lopis Raksasa secara simbolis oleh Bapak Walikota beserta Ibu, Wakil Walikota beserta Ibu, Ketua DPRD Kota Pekalongan, Kapolres Pekalongan Kota, Dandim 0710 Kota Pekalongan, Ketua Pengadilan Negeri Kota Pekalongan, Kepala Kejaksaan Negeri Kota Pekalongan dan Sekretaris Daerah Kota Pekalongan. Setelah selesai, kemudian Lopis Raksasa dibagikan secara tertib kepada ribuan pengunjung yang sudah menunggu sejak pagi hari (Laporan panitia dan Interview KH. Zainudin Ismail, tgl 11 Desember 2015)

\section{F. Asal Mula Tradisi Lopis Raksasa}

Tradisi lupis raksasa Kota Pekalongan tidak bisa dipisahkan dengan moment hari raya idul fitri. Hal ini dapat ditelisik dari waktu dan cikal bakal keberadaanya. Namun, ada 2 (dua) pendapat mengenai 
keterkaitan Tradisi lupis raksasa dengan tradisi syawalan yang muncul pertama kali di Krapyak.

Pendapat pertama dikemukakan oleh Zainudin Ismail, tokoh masyarakat setempat yang menyatakan bahwa tradisi lupis tidak dapat dipisahkan dengan puasa romadhon dan 1 syawal serta puasa Syawal yang diawali sesepuh Krapyak saat itu. Tradisi syawalan sudah rutin diadakan masyarakat Kelurahan Krapyak Gang 8 Kecamatan Pekalongan Utara sejak sekitar tahun 1885 . Tradisi yang sebenarnya tuntunan atau Sunah Nabi ini di awali oleh KH. Abdullah Siradj, ulama Krapyak, Putra Martoloyo II yang masih keturunan Tumenggung bahurekso, salah satu senopati kerajaan Mataram di Pekalongan, yang merupakan tokoh legendaris babad Pekalongan (Wawancara KH. Zainudin Ismail, tgl 8 Desember 2015).

Ustaz Abdulrachim Umar, salah satu cucu KH Abdullah Siradj, dalam Dirhamsyah (2014), awalnya KH. Abdullah Siradj melaksanakan puasa syawal, yaitu sehari setelah lebaran pertama, tanggal 2 sampai 7 syawal. Puasa ini kemudian diikuti oleh sebagian masyarakat Krapyak. Tradisi puasa setelah lebaran ini kemudian diikuti oleh masyarakat di luar Krapyak, sehingga meskipun hari raya, mereka tidak berkunjung atau bersilaturrahmi ke sana demi menghormati masyarakat Krapyak yang masih melanjutkan ibadah puasa syawal ${ }^{17}$.

Hal senada juga disampaikan Jaya Kusuma, Pegawai Pemkot Pekalongan, yang mengatakan bahwa ketaatan masyarakat Krapyak Kidul pada seorang Kiai untuk menjalankan puasa syawal 6 hari sudah terdengar masyarakat luas di luar daerah Krapyak. Mereka tidak akan bertamu atau berhalal bi halal di hari-hari puasa Syawal sebagai penghormatan dan penghargaan kepada masyarakat (Interview Jaya Kusuma, tgl 6 Desember 2015).

KH. Abdullah Siradj mempunyai penganut Islam yang kuat imannya, disamping berjuang menuntut kebebasan dari penjajah, juga mengajarkan agama Islam kepada penduduk. Diantaranya adalah Kiai Sulaiman, Kiai Ahmad, Kiai Bakir, dan Kiai Abdullah Wahab yang berasal dari Magelang. Merekalah yang mula-mula membuat lupis dengan ukuran kecil (normal) pada umumnya untuk menjamu tamu yang datang. (Interview Zainudin Ismail, tgl 8 Desember 2015).

\footnotetext{
${ }^{17}$ Dirhamsyah, M.,. Pekalongan Yang (Tak) Terlupakan sebuah Katalog Warisan Budaya Pekalongan. "Tradisi Syawalan di Krapyak". (Pekalongan: Kantor Perpustakaan dan Arsip Daerah Kota Pekalongan, 2014) hal. 96
} 
Hal ini senada dengan tulisan Sartono, dkk (1994) bahwa asal usul dibuatnya lopis untuk menjamu tamu, konon karena makanan itu yang paling tahan lama. Selain itu dahulu jenis makanan belum banyak seperti sekarang. Sedangkan suguhan lotis (lothekan) sebenarnya dahulu merupakan hasil tanaman pekarangan rumah penduduk. Saat ini penduduk Krapyak senang mengisi halamannya dengan tanaman buah-buahan yang bermanfaat $^{18}$.

Pendapat kedua dikemukakan Dirhamsyah, pemerhati sejarah budaya Pekalongan, yang mengatakan bahwa tradisi lupis tidak terkait langsung dengan tokoh KH. Abdullah Siradj, tokoh agama yang mengawali dan mengamalkan puasa syawal di daerah Krapyak. (Interview Dirhamsyah, tgl 7 Desember 2015).

Ketika ditanyakan apakah tradisi lupis raksasa terkait dengan amalan puasa sunah yang pelopori KH. Abdullah Siradj ? Dia menjawab

Tidak ada kaitannya. Jarak waktu sangat lama. KH. Abdullah Siradj, mulai sekitar tahun 1855. Itupun tidak lama karena pindah ke Magelang menghindari kejaran Kompeni Belanda saat itu. Sementara lopis mulai dibuat sekitar tahun 1950 terinspirasi Pidato Bung Karno saat itu (Dirhamsyah, tgl 7 Desember 2015)

Dia menulis dalam bukunya bahwa pada tahun $1855 \mathrm{KH}$ Abdullah Siradj mendirikan organisasi bernama Waraqatul Islam. Tujuannya untuk menggembleng para pemuda baik jasmani maupun rohani sebagai upaya persiapan melawan kompeni Belanda. Organisasi yang baru memiliki anggota 160 pemuda ini tercium oleh mata-mata Belanda, sehingga kemudian kompeni Belanda berniat menangkap KH. Abdullah Siradj hidup atau mati. Mengingat organisasi ini belum kuat sehingga para santrinya mengusulkan KH Abdullah siradj meninggalkan Pekalongan dan hijrah ke daerah Payaman Magelang. Di Magelang diangkat menjadi RAT Igama atau sekarang disebut Pengadilan Agama Magelang, bahkan menjadi menantu bupati Magelang pula ${ }^{19}$.

\footnotetext{
18 Sarjono, dkk.. Pekalongan Kota Batik. "Lopis" Ciri Khas Syawalan Pekalongan". (Pekalongan: Pemerintah Daerah Tingkat II Kotamadya Pekalongan, KADIN Daerah Tingkat II Kotamadya Pekalongan, 1994) hal. 107

${ }^{19}$ Dirhamsyah, M.,. Pekalongan Yang (Tak) Terlupakan sebuah Katalog Warisan Budaya Pekalongan. "Tradisi Syawalan di Krapyak". (Pekalongan: Kantor Perpustakaan dan Arsip Daerah Kota Pekalongan, 2014) hal. 96-97
} 
Lebih lanjut dalam bukunya dikatakan bahwa ketika Presiden Soekarno datang dalam rapat akbar di Lapangan Kebon Rodjo tahun 1950, beliau berpesan agar rakyat Pekalongan bersatu seperti lopis, sehingga setiap syawalan masyarakat selalu memotong lopis ${ }^{20}$.

Sampai saat ini pembuatan lopis tidak hanya di Krapyak tetapi sudah ada sekitar 4 tempat yang membuat lopis dengan ukuran raksasa (Zainudin Ismail, tgl 8 Desember 2015 dan Agung, pegawai KPAD Kota Pekalongan, tgl 7 Desember 2015). Namun, sebagai awal mula lupis berasal dari Krapyak gang 8 Kota Pekalongan. Tempat ini menjadi sasaran bagi pengunjung Syawalan tradisional atau biasa disebut sebagai "Krapyakan". Pengunjung datang dari berbagai daerah seperti Kalimantan, Sumatra, dan Kota-kota besar di Jawa lainnya. Pemerintah Kota Pekalongan merespon tradisi lupis raksasa ini sebagai aset daerah yang perlu dikembangkan keberadaanya dan menjadi ikon Kota Pekalongan itu sendiri.

\section{G. Makna Tradisi Lopis Raksasa bagi Masyarakat}

Syawalan atau Krapyakan di Pekalongan, bahkan ada yang menyebut dengan istilah "lopisan", dimanfaatkan sebagai media silaturrahmi, sambil menikmati hidangan khas lopis ketan yang disediakan oleh penduduk di setiap rumah. Selain lopis khusus yang disediakan pada upacara, penduduk menyediakan ukuran kecil (normal) untuk disuguhkan kepada setiap tamu yang berkunjung di rumahnya. Atau ada pula yang sengaja membuat untuk dijual kepada pengunjung yang ingin membawa oleh-oleh sebagai bukti menyaksikan syawalan di Krapyak dan dijajakan di sepanjang jalan Jlamprang ${ }^{21}$.

Kecuali makanan yang dibuat dari beras ketan itu, juga disediakan lothekan dari buah muda. Sarana lain yang mendukung semaraknya "Krapyakan", yaitu penduduk yang sebagian besar bermata pencaharian sebagai nelayan itu, menyediakan perahu untuk dikaryakan angkutan air. Jasa angkutan ini juga disediakan bagi pengunjung yang ingin pesiar ke laut dengan tarif relatif murah. (Sarjono, dkk, 1994: 106). Hal ini senada

${ }^{20}$ Dirhamsyah, M.,. Pekalongan Yang (Tak) Terlupakan sebuah Katalog Warisan Budaya Pekalongan. "Tradisi Syawalan di Krapyak". (Pekalongan: Kantor Perpustakaan dan Arsip Daerah Kota Pekalongan, 2014) hal. 97-98

21 Sarjono, dkk.. Pekalongan Kota Batik. "Lopis" Ciri Khas Syawalan Pekalongan". (Pekalongan: Pemerintah Daerah Tingkat II Kotamadya Pekalongan, KADIN Daerah Tingkat II Kotamadya Pekalongan, 1994) hal. 106 
dengan keterangan Jaya Kusuma (35) bahwa kemeriahan tradisi lupis raksasa saat ini sudah bertambah. Masyarakat menjadikan moment ini tidak saja kegiatan keagamaan tetapi dijadikan sebagai moment hiburan bagi masyarakat secara luas dari mana dan dari agama apapun mereka berasal (Interview Jaya Kusuma, tgl 6 Desember 2015)

Makna tradisi lupis bagi masyarakat Pekalongan juga tidak akan lepas dari semangat perjuangan pelopor dan sepak terjang $\mathrm{KH}$ Abdullah Siradj (Jaya Kusuma, tgl 6 Desember 2015). Sepanjang hidupnya KH. Abdullah Sirad adalah tokoh pergerakan, baik di bidang agama Islam maupun dalam perjuangan bangsa melawan penjajah Belanda. Dalam memimpin pergerakan, tokoh ulama asal Krapyak ini pernah mendirikan organisasi Warakatul Islam. Karenanya, ia oleh penjajah dianggap membahayakan dan harus ditangkap. Akibat ancaman itu, pemuda Abdullah sirad menyelamatkan diri ke daerah Magelang. Dalam persembunyian itu, ia dijadikan menantu oleh Bupati Magelang hingga akhir hayatnya. Sampai saat ini makam KH Abdullah Sirad yang berlokasi di belakang Masjid Payaman, di kenal masyarakat sebagai Makam Mbah Agung, yang pada saat-saat tertentu banyak dikunjungi orang untuk berziarah. Sayangnya tidak ada yang tahu persis kapan Mbah Agung Abdullah Sirad meninggal ${ }^{22}$. Hal ini menguatkan informasi dan ketokohan sesepuh Krapyak senada dengan informan-informan yang lain.

Sementara itu versi lain menyebutkan, Syawalan Krapyak mempunyai latar belakang perjuangan bangsa Indonesia melawan Belanda. Krapyak Kidul dan Krapyak Lor konon dulu merupakan daerah terisolasi. Itu memang sengaja dibuat oleh penjajah, karena masyarakatnya banyak yang menentang peraturan yang tidak sesuai dengan ajaran agama. Disebutkan, pada zaman perang Padri banyak murid Pangeran Diponegoro yang bersembunyi di daerah ini saat di serang Belanda ${ }^{23}$. Mereka adalah penganut Islam yang kuat imannya, disamping berjuang menuntut kebebasan dari penjajah, juga mengajarkan agama Islam kepada penduduk. Mereka adalah Kiai Sulaiman, Kiai Ahmad, Kiai Bakir, dan Kiai Abdullah Wahab yang berasal dari Magelang. (Interview Zainudin Ismail, tgl 8 Desember 2015)

22 Sarjono, dkk.. Pekalongan Kota Batik. "Lopis" Ciri Khas Syawalan Pekalongan". (Pekalongan: Pemerintah Daerah Tingkat II Kotamadya Pekalongan, KADIN Daerah Tingkat II Kotamadya Pekalongan, 1994) hal. 107

23 Sarjono, dkk. Pekalongan Kota Batik. "Lopis" Ciri Khas Syawalan Pekalongan". (Pekalongan: Pemerintah Daerah Tingkat II Kotamadya Pekalongan, KADIN Daerah Tingkat II Kotamadya Pekalongan, 1994) hal. 107 
Lopis yang terbuat dari beras ketan sebagai lambang iman yang kuat. Tanpa ikatan tali temali yang kokoh, membuat lopis menemui kegagalan. Demikan pula digambarkan pada kehidupan rumah tangga, harus saling kuat imannya antara suami istri. Begitu pula dalam kehidupan bermasyarakat. Bila sama-sama kuat, sebagaimana dilambangkan pada tali lopis, niscaya akan mudah menggapai kebahagiaan rumah tangga ${ }^{24}$. Ditambahkan bahwa pembungkus lopis raksasa ini menggunakan daun pisang. Hal ini mempunyai makna tersendiri seperti dikatakan oleh Zainudin Ismail sebagai berikut :

Pembungkus lupis adalah daun pisang. Pohon pisang mempunyai makna agung dimana selalu meninggalkan kebaikan bagi makhluk lain. Pohon pisang baru mengalami kematian atau setelah memberikan manfaat bagi manusia atau baru ditebang setelah berbuah. Filosopi ini yang ditularkan dan diharapkan ditiru oleh manusia dalam mengarungi kehidupannya yaitu memberi manfaat kebaikan bagi makhluk yang lain (Interview Zainudin Ismail, tgl 8 Desember 2015)

Khas syawalan di Krapyak Pekalongan adalah disajikannya makanan berupa lopis, semacam kudapan yang terbuat dari ketan. Mengapa kue lopis bukan ketupat?ini sebagai tanda yang membedakan antara tanggal 1 syawal dan 8 syawal. Selain itu, tokoh masyarakat setempat, Zaenudin Ismail, mengungkapkan bahwa lopis terbuat dari bahan dasar beras ketan memiliki daya rekat yang kuat, sehingga makanan ini diibaratkan sebagai lambang persatuan warga ${ }^{25}$.

\section{H. Nilai Kerukunan Umat Beragama pada Tradisi Lopis Raksasa}

Kerukunan hidup beragama dalam Ali (ed) seperti dikutip Rosidin (2015) menunjukkan pola hubungan antar verbagai kelompok umat beragama yang rukun, saling menghormati, saling menghargai damai, tidak bertengkar dan semua persoalan dapat diselesaikan sebaik-baiknya dan tidak mengganggu hubungan antarumat beragama di daerah tertentu. Selanjutnya dikatakan bahwa umat beragama merupakan penganut suatu

\footnotetext{
${ }^{24}$ Sarjono, dkk.. Pekalongan Kota Batik. "Lopis" Ciri Khas Syawalan Pekalongan". (Pekalongan: Pemerintah Daerah Tingkat II Kotamadya Pekalongan, KADIN Daerah Tingkat II Kotamadya Pekalongan, 1994) hal. 107

${ }^{25}$ Dirhamsyah, M.,. Pekalongan Yang (Tak) Terlupakan sebuah Katalog Warisan Budaya Pekalongan. "Tradisi Syawalan di Krapyak". (Pekalongan: Kantor Perpustakaan dan Arsip Daerah Kota Pekalongan, 2014) hal. 97
} 
agama yang berkembang di masyarakat. Sedang agama sendiri mempunyai tiga aspek, yaitu kepercayaan, peribadatan dan sosiologi. Aspek sosiologislah yang dapat memiliki hubungan antar sesama umat beragama $^{26}$. Kerukunan umat beragama sebagaimana Puslitbang Kehidupan dalam Survey Indeks Kerukunan Umat dilihat dari 3 variabel yaitu Toleransi, Kesetaraan dan Kerjasama. Variabel ini telah mencakup unsur kerukunan ketika dilaksanakan dalam kehidupan masyarakat

\section{Toleransi pada tradisi lopis raksasa}

Toleransi dan kerukunan antar umat beragama bagaikan dua sisi mata uang yang tak bisa dipisahkan satu sama lain. Kerukunan berdampak pada toleransi, atau sebaliknya toleransi menghasilkan kerukunan, keduanya menyangkut hubungan antar sesama manusia. Jika toleransi antar umat beragama dapat terjalin dengan baik dan benar, maka akan menghasilkan masyarakat yang rukun satu sama lain.

Dalam kaitan tradisi lopis raksasa mencerminkan sikap toleransi antar umat beragama dimana antar penduduk tercermin perbuatan yang menunjukkan umat saling menghargai, menghormati, menolong, mengasihi, dan lain-lain. Termasuk di dalamnya menghormati agama dan iman orang lain; menghormati ibadah yang dijalankan oleh orang lain, tidak merusak tempat ibadah, tidak menghina ajaran agama orang lain, serta memberi kesempatan kepada pemeluk agama menjalankan ibadahnya.

Pada proses persiapan pembuatan lopis raksasa semua membantu pelaksanaan sesuai kondisi masing-masing warga. Aktifitas fisik ditangani oleh para pemuda musholla sesuai tugas dan kewenangannya. Mereka mengahrgai dan menghormati serta mengasihi para orang tua untuk melaksanakan kegiatan yang tidak terlalu berat. Selain itu, aktifitas fisik banyak ditangani kaum pria dalam rangka menghormati kaum wanita mengingat besarnya lopis yang akan di buat.

Ketika ditanya apakah ada umat beragama lain yang ikut membantu dalam proses pembuatan lopis raksasa? KH. Zainudin Ismail berkata :

Sebenarnya siapa saja boleh membantu bahkan kalau pun ada umat agama lain akan membantu kami akan senang. Kami

${ }^{26}$ Rosidin,. Nilai-nilai Kerukunan dalam Kearifan Lokal Masyarakat Bawean Gresik. AlQalam Jurnal Penelitian Agama dan Sosial Budaya, Vol. 21 No. 1 Juni 2015 (Makassar : Kementerian Agama Balai Penelitian dan Pengembangan Agama Makassar, 2015) hal. 131 
akan terbuka dan senang kalau tradisi ini dapat menjadikan warga Kota Pekalongan bisa melaksanakan bersama-sama (Interview KH. Zainudin Ismail, tgl 11 Desember 2015)

Selama ini dalam proses persiapan belum pernah umat lain ikut menangani langsung kegiatan tradisi lopis raksasa tetapi sebenarnya akan diterima lebar-lebar manakala ada umat lain yang terjun langsung. Dalam pelaksanaannya diikuti ribuan pengunjung dari mana saja asalnya. Tidak ada batasan pemeluk agama tertentu yang boleh menghadiri tradisi lopis raksasa ini. Saling menghormati dan membantu pelaksanan tradisi lopis raksasa ini menandai tercipta toleransi diantara umat beragama, antar umat beragama dan umat beragama dengan pihak pemerintah sekalipun.

\section{Kesetaraan pada tradisi lupis raksasa}

Kesetaraan dimaknai sebagai pandangan dan sikap hidup menganggap semua orang adalah sama dalam hal hak maupun kewajiban. Hak atas melaksanakan agama beribadah dan kewajiban terhadap kehidupan bernegara dan bersosialisasi dengan penganut agama lain ${ }^{27}$.

Kesetaraan umat beragama ini ketika semua bekerja dan berbuat serentak seia sekata. Dalam mengerjakan persiapan sampai pelaksanaan tidak ada superioritas satu dengan lannya. Status sosial tidak dikedepankan dalam persiapan dan melaksanakan tradisi lopis raksasa. Tua muda bahkan anak-anak sangat antusias menyambut tradisi lopis raksasa. Semua mempunyai kesempatan yang sama untuk membantu dan mensukseskan perhelatan akbar tradisi lopis raksasa ini. Namun demikian, semua warga berpegang teguh pada tugas pokok yang telah di amanahkan sehingga kegiatan dapat berjalan dengan baik pada akhirnya.

Kenyataan ini sejalan dengan ukuran kesetaraan diantaranya bahwa semua tingkatan sama tidak ada superioritas, tidak diskriminatif dan hubungan timbal balik; mempunyai kesempatan yang sama dalam arti memberi kebebasan melakukan aktifitas keagamaan bagi orang lain dan perlindungan artinya tidak ada iri hati dan menghina satu sama lain. Kerjasama pada tradisi lopis raksasa

\footnotetext{
${ }^{27}$ Tim Peneliti Puslitbang Kehidupan,. "Survey Indeks Kerukunan Umat Beragama di Indonesia" Makalah Seminar hasil penelitian yang dselenggarakan oleh Puslitbang Kehidupan Keagamaan Badan Litbang dan Diklat Kementerian Agama RI pada tanggal 19 Nopember 2015 di Wisma Haji Jl. Jaksa Kebon Sirih Jakarta Pusat, 2015 hal. 7
} 
Kerjasama adalah kegiatan atau usaha yang dilakukan oleh beberapa orang atau lembaga untuk mencapai tujuan bersama ${ }^{28}$. Seluruh warga diperkenankan ikut berpartisipasi tanpa melihat latar belakang suku agama ras. Namun, kenyataanya belum ada warga beragama lain yang hadir dalam proses pembuatan lupis. Keseluruhan waktu pembuatan lopis raksasa membutuhkan waktu 5 hari 4 malam bukanlah pekerjaan mudah andai tidak ada sikap toleransi antar sesam dan kesetaraan dalam masyarakat. Di awali kegiatan kebersihan di dapur Lopis Raksasa mereka bahu-membahu membersihkan lantai, membersihkan dandang raksasa, membersihkan dandang-dandang kecil, merangkai beratus-ratus daun pisang dengan biting, membersihkan kronjot raksasa dan hal-hal kecil lainnya. Kerjasama warga masyarakat Gang 8 Krapyak Kidul merupakan cermin hidup rukun dalam kehidupan sosial keagamaan

Kegiatan pembuatan lopis raksasa dilakukan dengan bergotong royong antara lain menyiapkan tungku untuk tempat dandang raksasa, mencuci dan membilas beras ketan, menumbuk beras ketan yang sudah setengah matang dari dandang-dandang kecil, menumbuk beras ketan tadi untuk kemudian dimasukkan ke dalam kronjot lopis raksasa hingga membentuk lupis berukuran raksasa, merebus lopis raksasa, memastikan api tetap menyala dengan bahan bakar kayu bekas pembuatan kapal yang mempunyai daya panas tinggi selama 24 jam, kemudian membalik lopis raksasa, merebus kembali selama 24 jam, setelah selesai kemudian lopis raksasa dientas dari dandang raksasa, membuat panggung lopis raksasa dan terakhir memindahkan lopis raksasa yang sudah matang ke lokasi pemotongan lopis raksasa (Zainudin Ismail, tgl 11 Desember 2015 dan buku laporan panitia). Setiap tahap pembuatan lopis raksasa membutuhkan konsentrasi dan perhatian yang lebih untuk menghasilkan hasil terbaik. Kerjasama warga yang solid sangat menentukan keberhasilan makanan raksasa ini. Mereka tidak kenal lelah bahkan mempunyai semangat tinggi dan kompak secara bergantian membuat lopis raksasa ini sesuai tugas yang telah diamanahkan.

Kerjasama warga inilah wujud cerminan kerukunan umat beragama di Krapyak Kidul. Kebersamaan warga Kota Pekalongan akan

28 Tim Peneliti Puslitbang Kehidupan,. "Survey Indeks Kerukunan Umat Beragama di Indonesia" Makalah Seminar hasil penelitian yang dselenggarakan oleh Puslitbang Kehidupan Keagamaan Badan Litbang dan Diklat Kementerian Agama RI pada tanggal 19 Nopember 2015 di Wisma Haji Jl. Jaksa Kebon Sirih Jakarta Pusat, 2015 hal. 7 
mencapai puncaknya pada saat perayaan tradisi lopis raksasa yang rutin dilaksnakan pada hari ke delapan bulan Syawal.

\section{Belajar dari Kearifan Rasululah Muhammad SAW mengangkat hajar aswad}

Saat ini pembuatan lopis raksasa tidak hanya dilakukan di Krapyak Gang 8 Kota Pekalongan sebagai cikal bakal atau asal muasal tradisi lopis. Menurut informan, Jaya Kusuma (39) bahwa pembuatan lopis raksasa juga dilakukan di Krapyak Lor bahkan tempat lain di Slamaran juga ada (Interview Jaya Kusuma, tgl 6 Desember 2015). Hal ini dibenarkarkan oleh penasehat Musholla Darunna'im bahwa sekarang ada 4 tempat yang membuat lopis dengan ukuran besar. Tidak ada larangan karena semua ingin berbuat baik kepada tamunya saat syawalan. Namun demikian, sesuai hasil kesepakatan tahun 2014 bersama Lurah Krapyak ditegaskan bahwa pusat pemotongan dilakukan di Musholla Darunna'im Krapyak Gang 8 sebagai cikal bakal tradisi lopisan (KH. Zainudin Ismail, tgl 11 Desember 2015).

Ada indikasi saling berlomba dalam membuat lopis raksasa terbesar di antara mereka. Fenomena ini perlu mendapat perhatian dari tokoh agama maupun tokoh masyarakat di Kota Pekalongan. Kalau berkaca dari kearifan Rosulullah SAW saat menghadapi suku-suku yang memperebutkan dapat mengangkat hajar aswad saat itu, maka ada baiknya ketika pembuatan dan pemotongan lopis raksasa atau paling tidak pada proses penempatan lopis raksasa di tempat upacara pemotongan melibatkan perwakilan masyarakat/pemuda di lingkungan musholla yang berada di daerah setempat.

\section{Kesimpulan}

Kearifan lokal, salah satunya tradisi lopis raksasa dapat menjadi sarana pendukung program pembangunan Pemerintah Kota Pekalongan khususnya dan pemerintah Indonesia pada umumnya. Hal ini akan berhasil sepanjang upaya yang dilakukannya terencana, terarah dan tepat dalam mengkomunikasikan dengan masyarakat pelaku tradisi itu sendiri.

Ada dua pendapat mengenai tradisi lopis raksasa, pertama tradisi lopis raksasa tidak dapat dipisahkan dengan amalan Sunah Nabi SAW mengenai puasa Syawal oleh KH. Abdullah Siradj, ulama Krapyak sekitar tahun 1885. Kebiasaan menyambut tamu setelah puasa Syawal dilakukan para pengikutnya dengan suguhan jajanan lupis hingga sampai sekarang. Kedua, tradisi lopis tidak ada kaitan dengan sepepuh Krapyak mengingat 
kurun waktu dan baru populer tahun 1950 terinspirasi pidato akbar Presiden Soekarno di lapangan Kebon Rojo Pekalongan. Lupis raksasa dijadikan pusat perhelatan syawalan sedangkan lupis-lupis berukuran kecil disediakan warga di setiap rumah warga.

Makna lopis terbuat dari beras ketan sebagai lambang iman yang kuat, diikat dengan tali temali sebagai lambang keeratan yang kokoh agar tidak menemui kegagalan. Dalam bermasyarakat dan bernegara apabila sama-sama kuat niscaya akan mudah menggapai kebahagiaan bersama. Pembungkus lupis adalah daun pisang dimana pohon pisang selalu meninggalkan kebaikan bagi makhluk lain. Pohon pisang baru mengalami kematian atau setelah memberikan manfaat bagi manusia atau baru ditebang setelah berbuah.

Tradisi lopis raksasa yang sudah turun temurun berjalan membutuhkan pengelolaan yang baik mulai persiapan, pelaksanaan hingga perayaan pemotongan melibatkan masyarakat semua kalangan. Sikap toleransi, kesetaraan dan kerjasama yang makin terjalin erat dalam tradisi lopis raksasa inilah yang menjadikan kerukunan umat beragama semakin terjaga dalam membangun Kota Pekalongan sebagai miniatur bangsa Indonesia.

Informasi lapangan yang diperoleh menuntun peneliti memberikan saran agar semua pihak terkait tradisi selalu berkoordinasi dan komunikasi sebaik-baiknya. Pertama, masyarakat Krapyak Gang 8 Kota Pekalongan sebaiknya melibatkan masyarakat di luar atau perwakilannya agar terjalin silaturrahim secara luas. Dengan mengambil pelajaran Rasulullah SAW maka pada saat pemasangan lopis raksasa hendaknya melibatkan perwakilan pelaku lopis raksasa di tempat lain. Kedua, Pemerintah Kota Pekalongan dapat mendukung dan mengembangkan potensi tradisi lopis raksasa sebagai ikon Kota Pekalongan dengan tetap memelihara kraetifitas warga dan tidak mengesampingkan makna luhur yang telah ada. Ketiga, Kementerian Agama dan FKUB Kota Pekalongan dapat menjadikan tradisi lopis raksasa ini sebagai sarana mengokohkan kerukunan umat beragama Kota Pekalongan.

\section{DAFTAR PUSTAKA}

Ali, Mukti A. 1975. Agama dan Pembangunan di Indonesia VI. Jakarta: Biro Hukum dan Humas Departemen Agama

Arikanto, Suharsimi, 2010, Prosedur Penelitian Suatu Pendekatan Praktik, Jakarta: PT Rineka Cipta 
Dirhamsyah, M., 2014. Pekalongan Yang (Tak) Terlupakan sebuah Katalog Warisan Budaya Pekalongan. "Tradisi Syawalan di Krapyak". Pekalongan: Kantor Perpustakaan dan Arsip Daerah Kota Pekalongan

Mujimin, dkk., 2007. Tradisi Syawalan Di Krapyak Pekalongan : Sebuah Kajian Folklor. Semarang : Jurusan Bahasa dan Sastra Indonesia Universitas Negeri Semarang

Rosidin, 2015. Nilai-nilai Kerukunan dalam Kearifan Lokal Masyarakat Bawean Gresik. Al-Qalam Jurnal Penelitian Agama dan Sosial Budaya, Vol. 21 No. 1 Juni 2015 Makassar : Kementerian Agama Balai Penelitian dan Pengembangan Agama Makassar

Sarjono, dkk. 1994. Pekalongan Kota Batik. "Lopis" Ciri Khas Syawalan Pekalongan". Pekalongan: Pemerintah Daerah Tingkat II Kotamadya Pekalongan, KADIN Daerah Tingkat II Kotamadya Pekalongan

Seksi Integrasi Pengolahan dan Diseminasi Statistik. 2015. Kota Pekalongan Dalam Angka Tahun 2014. Pekalongan: Badan Pusat Statistik Kota Pekalongan

Seksi Integrasi Pengolahan dan Diseminasi Statistik. 2015. Kecamatan Pekalongan Utara Dalam Angka Tahun 2014. Pekalongan: Badan Pusat Statistik Kota Pekalongan

Supandi, 2014. Makna Dan Pengaruh Tradisi Syawalan Bagi Masyarakat Multi-Agama Di Komplek Mandala Asri Yogyakarta. Yogyakarta : Jurusan Perbandingan Agama Fakultas Ushuluddin Dan Pemikiran Islam Universitas Islam Negeri Sunan Kalijaga Yogyakarta

Tim Peneliti Puslitbang Kehidupan, 2015 "Survey Indeks Kerukunan Umat Beragama di Indonesia" Makalah Seminar hasil penelitian yang dselenggarakan oleh Puslitbang Kehidupan Keagamaan Badan Litbang dan Diklat Kementerian Agama RI pada tanggal 19 Nopember 2015 di Wisma Haji Jl. Jaksa Kebon Sirih Jakarta Pusat

Nanda, 2015. Sejarah Syawalan kaliwungu. http://kaliwungu.org/sejarahsyawalan-kaliwungu, tgl 21 Desember 2015

http://www.kemenagkotapekalongan.com/kuau.php, tgl 10 Desember 2015 